\title{
Tratamento homeopático da papilomatose bovina
}

Thaiona Ferreira ${ }^{[a]}$, William Wagner ${ }^{[a]}$, Vanessa Candida Ficagna ${ }^{[b]^{*}}$

[a] Curso de Medicina Veterinária, Centro Universitário Dinâmica das Cataratas (UDC), Foz do Iguaçu, PR, Brasil

[b] Médica veterinária, Prefeitura Municipal de Corbélia, Corbélia, PR, Brasil

*Autor correspondente

e-mail: vficagna@hotmail.com

\section{Resumo}

A papilomatose bovina é uma doença viral, infectocontagiosa, caracterizada por lesões hiperplásicas benignas em epitélio cutâneo e mucoso. É amplamente disseminada pelo mundo e ocorre em diversas espécies de mamíferos e aves, conhecida também como "figueira", "verruga", "fibropapilomatose" e "epitelioma contagioso", considerada uma doença cosmopolita intimamente associada à imunidade celular animal. Os bovinos de todas as raças, tanto de corte quanto de leite, são susceptíveis. Os papilomas são tumores benignos de tamanhos, cores e formas variadas, extremamente incômodos para os animais, que afetam a produção de leite e carne, predispondo a ocorrência de infecções bacterianas secundárias e miíases. A contaminação dos animais ocorre principalmente pelo contato com ambientes e animais contaminados, ou por meio de fômites. Os tratamentos disponíveis são baseados na remoção dos tumores, no uso de vacinas autógenas, fármacos à base de clorobutanol, uso de produto químico direto sobre o papiloma, auto-hemoterapia e emprego de medicamentos homeopáticos. 0 objetivo do presente estudo foi avaliar o emprego do tratamento para a papilomatose viral bovina, com o uso de medicamento homeopático, após a repertorização, analisando a presença de lesões características. Foi realizado o tratamento homeopático em uma vaca leiteira da raça Jersey, com 32 meses, em lactação e que apresentava diversos papilomas nos tetos. Após a consulta inicial realizada pelo médico veterinário, este realizou a repertorização dos sinais clínicos, relacionados ao comportamento do animal, usand o o programa HomeoPro, que resultou na indicação de dois medicamentos homeopáticos: a Thuya ocindetalis e o Causticum. No tratamento inicial foi utilizado a Thuya ocindetalis em CH 12, administrada duas vezes ao dia antes da ordenha. Na terceira visita, após 2 meses de tratamento, após consulta clínica, foi alterado o medicamento homeopático para o Causticum em CH 18, mantendo a mesma forma de administração. Na última visita de acompanhamento técnico verificou-se a 
redução do tamanho dos tumores papilomatosos principalmente na região do úbere e tetos, com destaque aos tetos posteriores que, conforme relatos dos proprietários, melhoraram em sua totalidade, e redução dos tumores na região do olho direito. Uma vez que o animal ainda apresenta lesões características na região do corpo, pescoço, teto anterior direito e face, o proprietário foi orientado a continuar com o tratamento. Os resultados são satisfatórios até o momento, pois o animal não tem apresentado sensibilidade durante o processo de ordenha mecânica. 0 uso de medicamentos homeopáticos, devido as suas características de diluição infinitesimal, não produz resíduos no leite e tem sido amplamente utilizado. Sendo assim, sugere-se a realização de novos estudos para avaliação da homeopatia no tratamento de doenças em animais. 